\title{
Heterosis and genetic diversity in the crossings of gladiolus cultivars Amsterdam and White Prosperity
}

\author{
Mohammad Hossein Azimi ${ }^{1 *}$
}

\begin{abstract}
Gladiolus is one of the most important and popular cut-flower bulbous in Iran. The aim of this research was to produce new, high-quality hybrids through hybridization. We generated two promising hybrids (OPRC16 and OPRC57) combination from the varieties "Amsterdam" and "White Prosperity". The Research was conducted in Ornamental Plants Research Center in Mahallat from 2014 to 2018. Values of Hm for traits were defined as the difference between the mid-F1 value and the mid-parent value, Mean Mid-parent Heterosis (MPH) or (Hmp) and High Parent Heterosis (HPH) or (Hsp). The results showed that the morphological analysis revealed the heredity and variation in the promising hybrids. The results for the hybrid OPRC16 showed that the Hm and Hmp values were negative for peduncle length but positive for other traits. The Hsp value was observed to be negative for the traits of peduncle length, leaf width, stem diameter, and cormels diameter, but it was positive for other traits. According to the results for the hybrid OPRC57, the Hm and Hmp values were negative for plant height, floret number, peduncle length, floret diameter, stem diameter, spike length, cormles weight, and cormlet diameter and negative for other traits. Peduncle length was positive in other traits. The Hmp value was negative for peduncle length, but positive for other traits. The Hsp value was recorded to be positive for leaf length, bud diameter, vase life, cormlet number, and cormles yield but negative for other traits. All in all, OPRC57 showed a negative heterosis in most traits. Based on the results, when 'Amsterdam' is used as the maternal plant in crosses, it has more positive heterosis effects than when it is used as the paternal parent. These results indicate that major of traits in the phenotypic and genetic diversity coefficient was very low, indicating that they had less environmental effects, since the genotypes were cultivated under similar and controlled conditions.
\end{abstract}

Keywords: morphological, heterosis, hybridization, diversity.

\section{Resumo}

Heterose e diversidade genética nos cruzamentos das cultivares de gladíolo Amsterdam e White Prosperity O gladíolo é um dos bulbos de flores de corte mais importantes e populares do Irã. O objetivo desta pesquisa foi produzir novos híbridos de alta qualidade por meio de hibridação. Duas combinações de híbridos promissores (OPRC16 e OPRC57) foram produzidas à partir das variedades "Amsterdam" e "White Prosperity". A pesquisa foi realizada no Centro de Pesquisa de Plantas Ornamentais em Mahallat de 2014 a 2018. Os valores de Hm para as características foram definidos como a diferença entre o valor médio da F1 e o valor do meio dos pais, Heterose Média dos Pais Média (MPH) ou (Hmp) e Heterose Alta dos Pais (HPH) ou (Hsp). Os resultados mostraram que a análise morfológica revelou a hereditariedade e a variação nos promissores híbridos. Os resultados para o híbrido OPRC16 mostraram que os valores de $\mathrm{Hm}$ e Hmp foram negativos para o comprimento do pedúnculo, mas positivos para outras características. Observou-se que o valor de Hsp foi negativo para as características de comprimento do pedúnculo, largura das folhas, diâmetro do caule e diâmetro dos cormos, mas foi positivo para outras características. De acordo com os resultados para o híbrido OPRC57, os valores de Hm e Hmp foram negativos para altura da planta, número de flores, comprimento do pedúnculo, diâmetro da flor, diâmetro do caule, comprimento da haste, peso dos cormos e diâmetro dos cormos, e negativos para outras características. O comprimento do pedúnculo foi positivo em outras características. O valor de Hmp foi negativo para o comprimento do pedúnculo, mas positivo para outras características. O valor de Hsp foi positivo para o comprimento da folha, diâmetro da brotação, vida útil do vaso, número de cormos e rendimento de cormos, mas negativo para outras características. Ao todo, o OPRC57 mostrou heterose negativa para a maioria das características. Com base nos resultados, quando 'Amsterdam' foi utilizada como planta materna em cruzamentos, houve mais efeitos positivos de heterose do que quando foi utilizada como matriz paterna. Esses resultados indicam que a maioria das características do coeficiente de diversidade fenotípica e genética foi muito baixa, indicando que tiveram menos efeitos ambientais, uma vez que os genótipos foram cultivados em condições semelhantes e controladas.

Palavras-chave: morfologia, heterose, hibridação, diversidade.

${ }^{1}$ Ornamental Plants Research Center (OPRC), Horticultural Sciences Research Institute (HSRI), Agricultural Research, Education and Extension Organization (AREEO), Mahallat, Iran. *Corresponding author: m.h.azimi58@gmail.com,mh.azimi@areeo.ac.ir

Received Sep 29, 2019 | Accepted Apr 20, 2020| Available online May 6, 2020

Licensed by CC BY 4.0

https://doi.org/10.1590/2447-536X.v26i2.2095

Area Editor: Gilmar Schafer 


\section{Introduction}

Gladiolus is the next most popular cut-flower after rose and chrysanthemum in Iran. It is being grown over an area of 350 ha and centers of production are in pakdasht, varamin, karaj, damavand, mahallat, dezful and jiroft (Ministry of Agriculture Jihad, 2015). Gladiolus (Gladiolus grandiflora Hort.) belongs to Iridaceae family (Ranjan et al., 2010), and is usually called as the queen of bulbous flowers (Randhawa and Mukhopadhyay, 2000). So, Gladiolus popularly known as Sword lily or Corn Lily and originated from South Africa (Poon et al., 2012).

The genus of Gladiolus contains over 276 species throughout the world, but they are mostly native to the western, southern, and eastern parts of Africa although 12 species have been originated from the Mediterranean regions (Rina \& Hiroshi, 2016). In Iran it is one of the main bulbous cut flowers and also in the world which has an important role in exporting as cut flowers (Azimi, 2020b).

Evaluations on genetic association are useful to ascertain the important component trait on which chose can be made (Choudhary et al., 2011). Several studies have been conducted on gladiolus: phenology (Schwab et al., 2015); estimation of genetic variability (Azimi, 2020b, Rashmi and Kumar, 2014); heritability and genetic advance (Patra and Mohanty, 2014); genotypic and phenotypic variability (Pattanaik et al., 2015, Bhujbal et al., 2013); and hybridization (Ohri and Khoshoo, 1983a; 1983b; Hossain et al., 2012; Azimi, 2019). In gladiolus, new varieties are evolved through hybridization which is recognized as the most important sources of evolution and crop improvement. Crossing different plant varieties aims to generate wider genetic variation and to use heterosis of hybrid progenies (Joshi et al., 2001). Interspecific hybridization is a commonly used method in different close related species for producing off-springs with new characteristics. Among the three different methods of pollination of gladiolus cultivars via natural self-pollination, artificial selfpollination and open pollination, artificial self-pollination generally gave the best results (Dhaduk et al., 1987). Inter-varietal hybridization is another common way for transferring desirable attributes between different cultivars and producing progenies with new characteristics (Azimi et al., 2018; Yang et al., 2015; Zamani et al., 2010). Azimi (2020a, b) and Azimi and Banijamali (2019) indicated significant differences between gladiolus genotypes for morphological traits. The hybrid plants had the highest variability, making them the most indicated for future improvement programs. Diallel analysis provide the greatly influences genetic information for breeding programs (Fan et al., 2014). Reduced natural cross-pollination may have resulted from a lack of pollinating insects (Ohri and Khoshoo, 1981).

Moreover, participation of inhibitory specificities of pollen cholinesterase in the pollen-stigma interaction failed to obtain matured seed from the crosses (Semenova and Roshchina, 1993). Presence of dry type of gladiolus stigma may be another reason for their incompatibility (Clarke et al., 1977). Gladiolus varieties are good general combiners for many traits and additive type of gene action has been noticed for many traits (Kumar et al., 2008). Corms and cormels are the propagating materials for gladiolus. Cormles grow in between mother and daughter corms (Larson, 1992). Gladiolus is largely propagated by corms and cormles whereas seeds propagation is followed to evolve new cultivars and for the recovery and maintenance of the threatened germplasm. Moreover, seed production is higher than cormles production in gladiolus (Gonzalez et al., 2003). Although, plants raised from seeds require four seasons to come to bloom under ordinary conditions but under best cultural treatments, it may be reduced to two seasons (Bose et al., 2003) and plants produced from seeds can flower in the second year (Cohat, 1993). Environmental factor in combination with genetic and physiological factors play an important role in determination of plant potential for propagating material. These characters appear to be under strong genetic control (Sukarin et al., 1987; Roy et al., 2004). The decision on the tip-top improvement breeding, on the appropriate selection intensity, and on the characteristics to be considered in the selection is based on the knowledge of the genetic structure of the population (Singh et al. 2018).

The key for any success of any genetic breeding program lies in the availability genetic variability for desired traits (Heller, 1996). Wide hybridization enables the interspecific gene transfer, which may lead to the additional source of variation for the desirable characters (Anandhi et al., 2013) and Takatsu et al., (2001) made interspecific hybridization between a modern cultivar of Gladiolus grandiflora Hort. $(2 \mathrm{n}=60)$ and the wild species G. tristis $\mathrm{L} .(2 \mathrm{n}=30)$ to introduce characteristics of the wild species in to the cultivated one and reported best pollen tube growth, fertility, and fruit set in their cross at low air temperatures for $\mathrm{F} 1$ hybrid plants production (Takatsu et al., 2001). Hossain et al. (2012) indicate the existence of wide variability among the gladiolus genotypes considering crossing parameters and variations were observed for seed. Significant differences in all traits and a wide variation in progenies observed for all traits among the gladiolus genotypes in F1 seed (Azimi, 2019).

To keep up flower diversity according to the new consumer demands in the ornamental plant industry, plant breeders need to create a diversification and to produce new flowers having new characteristics. Therefore, two popular cultivars of Gladiolus were hybridized in order to produce new hybrids with probable potential of commercial importance in the ornamental industry. This is the first investigation of Gladiolus hybridization in Iran and can open new horizon for designing new breeding programs between commercial and wild Gladiolus in future.

\section{Material and Methods}

\section{Plant material}

The two varieties of gladiolus include 'Amsterdam' (P1) and 'White prosperity' (P2) were used for hybridization. It was done in the ornamental plants research center (OPRC), Mahallat, Iran (2014-2018). 


\section{Hybridization program}

After spike emergence of gladiolus varieties, a full diallele crossing was carried out among the two varieties to study seed setting in cross combinations and the combining ability of seed characters. In the female parent, flowers at pre-anthesis stage were selected for emasculation. Emasculation was carried out between early evenings and bagged with butter paper cover. Similarly, in the male parents, a few selected flower buds at pre-anthesis stage were bagged without emasculation to avoid contamination by foreign pollen for collection of pollen grains. Pollen from bagged flowers of pollen parents were collected between morning and Sundown and dusted on the stigma of emasculated flowers of the respective female parents. The flowers were bagged with butter paper and then labelled. The covers were removed after ensuring proper pod set. The F1 pods were harvested at full physiological maturity, when the capsules start to burst. Each individual cross was harvest by hand.
Seedbed preparation, sowing and produce cormles

All seeds of parental crosses (300 seeds from each hybrid) were planted on well prepared and raised seedbeds to produce seedlings. Before sowing in the trays, the seeds are rubbed between two layers of cloth to remove the waxy covering and finally shake for 6 hours. It has been reported that the waxy covering contains some substances that retard the germination process. Seeds are sown in 1.5-2.0 cm deep in trays. The seeds planted in January in the tray with contents $30 \%$ perlite and $70 \%$ coco peat in the greenhouse at temperature of $23 \pm 4{ }^{\circ} \mathrm{C}$ and humidity $65 \% \pm 5 \%$, the moisture content of the bed must be maintained. Hundred seeds were planted for each replication. The seedlings matured in 125 days in greenhouse condition and were harvested cormles. Characteristic and pictures (Fig 1) of all steps are in the Table 1. Among the populations created, two hybrids were selected and propagated. The total entries were therefore four genotypes (parents and superior crosses: OPRC16 and OPRC57) chosen for evaluation.
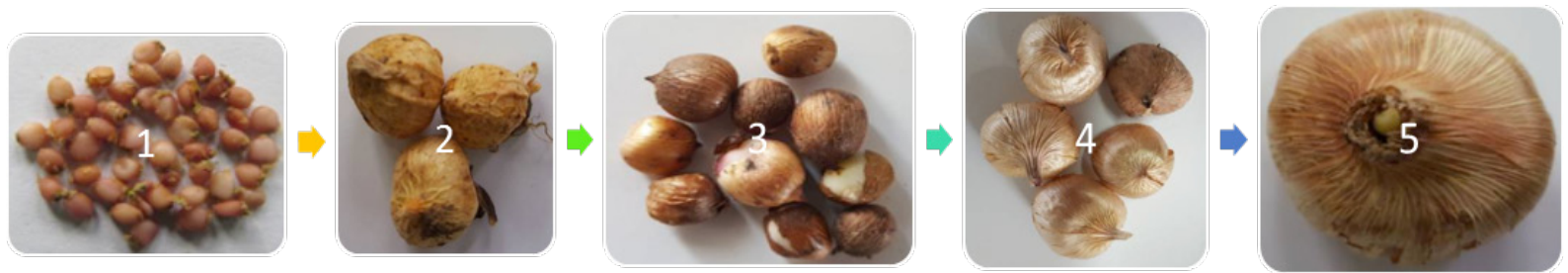

Figure 1. Seed alteration to corm in during growth.

Table 1. Seed alteration to Corm with applied information (2014-2018)

\begin{tabular}{|c|c|c|c|c|c|c|}
\hline Steps & Description & $\begin{array}{c}\text { Yield } \\
\text { (number) }\end{array}$ & $\begin{array}{c}\text { Mid-Rest } \\
\text { period (day) }\end{array}$ & $\begin{array}{c}\text { Growth period } \\
\text { (day) }\end{array}$ & $\begin{array}{c}\text { Mid-Weight } \\
\text { (g) }\end{array}$ & $\begin{array}{l}\text { Diameter } \\
(\mathbf{m m})\end{array}$ \\
\hline 1- seed & $\begin{array}{c}125 \text { days } \\
\text { after planting } \\
\text { becomes mini- } \\
\text { corm }\end{array}$ & $\begin{array}{l}10 \text { to } 15 \text { seeds } \\
\text { per capsule are } \\
\text { formed }\end{array}$ & - & $\begin{array}{c}35 \text { days after } \\
\text { the cross can be } \\
\text { harvest }\end{array}$ & $\begin{array}{c}0.08 \mathrm{~g} \\
(10 \mathrm{seed})\end{array}$ & - \\
\hline 2- Cormlet-1 & $\begin{array}{c}\text { no flowering } \\
\text { ability }\end{array}$ & 3 mini-corm & 30.00 & $110.00 \pm 10$ & 0.22 & $7.00 \pm 4.36$ \\
\hline 3- Cormlet-2 & $\begin{array}{l}\text { no flowering } \\
\text { ability }\end{array}$ & $\begin{array}{c}3 \text { mini-corm } \\
\text { and } \\
5 \text { small } \\
\text { cormlets }\end{array}$ & 35.00 & $120.00 \pm 20.00$ & 1.33 & $0.74 \pm 10$ \\
\hline $\begin{array}{c}\text { 4- Corm-1 } \\
\text { (Commercial } \\
\text { corm) }\end{array}$ & $\begin{array}{c}\text { flowering } \\
\text { ability }\end{array}$ & $\begin{array}{l}7 \text { mini-corm, } \\
3 \text { small, and } \\
2 \text { medium } \\
\text { cormlets }\end{array}$ & 35.00 & $90.00 \pm 10.00$ & 7.46 & $27.00 \pm 18.00$ \\
\hline $\begin{array}{c}\text { 5- Corm-2 } \\
\text { (Commercial } \\
\text { corm) }\end{array}$ & $\begin{array}{l}\text { flowering } \\
\text { ability }\end{array}$ & $\begin{array}{c}10 \text { mini-corm, } \\
7 \text { small, and } \\
5 \text { medium } \\
\text { cormlets }\end{array}$ & 35.00 & $85.00 \pm 15.00$ & 28.44 & $46.54 \pm 32.00$ \\
\hline
\end{tabular}




\section{Data collection}

Hybrids and parents were cultivated based on completely randomized block design with three repetitions. At flowering period in greenhouse condition (February, 2017), 28 morphometric traits were recorded based to the distinctness, uniformity and stability (DUS) test, according on International Union for the Protection of New Varieties of Plants (UPOV, 2013) instructions. Ornamental traits were measured using digital ruler and caliper, and flower color was recorded according to the standard RHS color chart (the royal horticulture society, London).

Color measurements were performed on digital images and analyzed by using color tester software version 3 (Strecker et al., 2010). Indices of 'a', 'b' and 'L' indexes were measured and $\Delta \mathrm{E}$ was calculated as follows:

$\Delta \mathrm{E}=\sqrt{\Delta} \mathrm{a}^{2}+\Delta \mathrm{b}^{2}+\Delta \mathrm{L} 2$

Where: $a$ - tendency of flower color from green to red ( -70 for dark green and +70 for dark red); $b$ - tendency of flower color from blue to yellow ( -70 for blue and +70 for yellow); $L$ - brightness and lucidity of flower ( 0 for dark and 100 for white); $\Delta E$ - degree of color changing and its differences across flower.

\section{Data analysis}

Analysis of variance was performed for all of the morphometric measured traits by SAS software ver. 6 . Descriptive statistics including mean, minimum, maximum values as well as coefficient of variation ( $\mathrm{CV} \%$ ) were calculated for all traits. Heterosis is compute as mid-parent heterosis or ( $\mathrm{Hm})(\mathrm{Li}$ and $\mathrm{Wu}, 1997)$. Values of $\mathrm{Hm}$ for traits was defined as the difference between the mid-F1 value (mean value of that trait in F1 populations) or (Fm) and the mid-parent value (MPV), that is, Hm= Fm-MPV; MPV is the mean value of that trait in the two parents (Yang et al., 2015). Percentage of heterosis (percent) was calculated according to Hallauer et al. (1988). Below formulas were used to compute relative heterosis in comparison with average of parents (a) and superior parent (b):

a) Mean Mid-parent Heterosis $(\mathrm{MPH})$ or $(\mathrm{Hmp})=$ (Mean Hybrid value - Mean parent value / Mean parent value) $\times 100$

b) High Parent Heterosis $(\mathrm{HPH})$ or $(\mathrm{Hsp})=($ Mean Hybrid value - High parent value / High parent value) $\times 100$

\section{Statistical analysis}

This study randomized complete block design with three replications was conducted. Statistical analysis included descriptive statistics, analysis of variance, and mean comparison with Duncan's multiple range tests. All statistical analysis was performed with SAS 9.1 software.

\section{Results and Discussion}

Analysis of variance and descriptive statistics of quantitative traits

The comparison of the traits between the promising hybrid OPRC16 and the parents showed that they differed significantly for all traits except for leaf width, spike length, vase life, and cormles diameter. The coefficient of variations $(\mathrm{CV})$ between the traits ranged from 0.00 to 12.20 percent. The highest $\mathrm{CV}$ was related to cormlet weight and the lowest to vase life (Table 2).

Concerning the traits of the promising hybrid OPRC57 and the parents, significant differences were observed in all traits unless vase life. The CV was in the range of 0.00-30.69 percent. The highest and lowest CVs were obtained for spike length and vase life, respectively (Table 3). Traits with higher CV exhibit a wider range of quantity, which is regarded as a wider range of selection for that trait. 
Table 2. Genetic characteristics of ornamental traits in Gladiolus grandiflorus ‘Amsterdam’ (p1: †), Gladiolus grandiflorus ‘White Prosperity’ (p2: §̋) and their F1 hybrid

\begin{tabular}{|c|c|c|c|c|c|c|c|c|c|c|c|}
\hline \multirow{2}{*}{ Ornamental traits } & \multicolumn{3}{|c|}{ Parent plants } & \multicolumn{7}{|c|}{ Hybrid F1 (oprc16) } & \multirow{2}{*}{$\begin{array}{l}\text { Parent and F1 } \\
\text { Mean Square }\end{array}$} \\
\hline & $\hat{0}$ & 우 & MPV & mid-F1 value & SD & CV (\%) & Extreme value & $\mathrm{Hm}$ & Hmp & Hsp & \\
\hline Plant height (cm) & 128.00 & 143.20 & 135.61 & 193.0 & 9.65 & 5.00 & $183.40-202.70$ & 57.40 & 42.32 & 34.78 & $35.05^{*}$ \\
\hline Num. of florets per spike & 12.10 & 16.50 & 14.31 & 19.0 & 0.95 & 4.99 & $18.10-20.00$ & 4.70 & 32.77 & 15.15 & $0.36^{*}$ \\
\hline Peduncle length $(\mathrm{cm})$ & 19.94 & 20.53 & 20.24 & 17.00 & 0.85 & 4.99 & $16.20-17.90$ & -3.20 & -16.01 & -17.19 & $0.94 *$ \\
\hline Floret width (cm) & 8.39 & 9.43 & 8.91 & 12.00 & 0.60 & 5.00 & $11.40-12.60$ & 3.10 & 34.68 & 27.21 & $0.10^{*}$ \\
\hline Floret length $(\mathrm{cm})$ & 6.59 & 7.82 & 7.20 & 9.00 & 0.45 & 5.00 & $8.55-9.45$ & 1.80 & 25.00 & 15.16 & $0.17 * *$ \\
\hline Leaf width $(\mathrm{cm})$ & 2.85 & 4.71 & 3.78 & 4.20 & 0.21 & 5.00 & $3.99-4.41$ & 0.40 & 11.11 & -10.76 & $0.01^{\mathrm{ns}}$ \\
\hline Leaf length $(\mathrm{cm})$ & 51.30 & 59.30 & 55.30 & 79.00 & 3.95 & 5.00 & $75.10-83.00$ & 23.70 & 42.86 & 33.21 & $23.66^{* *}$ \\
\hline Stem diameter (mm) & 10.67 & 18.08 & 14.38 & 11.80 & 0.60 & 5.08 & $11.20-12.40$ & -2.60 & -17.94 & -34.74 & $0.69^{* *}$ \\
\hline Spike length (cm) & 42.47 & 52.25 & 47.36 & 71.00 & 3.55 & 5.00 & $67.45-74.55$ & 23.60 & 49.92 & 35.89 & $0.16^{\mathrm{ns}}$ \\
\hline Bud diameter (mm) & 8.07 & 7.67 & 7.87 & 10.44 & 0.52 & 4.98 & $9.92-10.96$ & 2.60 & 32.66 & 36.17 & $0.37 *$ \\
\hline Vase life (day) & 7.00 & 9.00 & 8.00 & 11.00 & 0.00 & 0.00 & $11.00-11.00$ & 3.00 & 37.50 & 22.22 & 0.00 \\
\hline Corm weight (g) & 20.11 & 46.50 & 33.30 & 88.21 & 0.52 & 0.59 & $87.61-88.51$ & 54.90 & 164.89 & 89.71 & $11.13 * *$ \\
\hline Corm diameter (mm) & 37.26 & 58.15 & 47.71 & 84.76 & 1.10 & 1.30 & $83.66-85.86$ & 37.10 & 77.66 & 45.75 & $56.44 * *$ \\
\hline Num. of cormlets per plant & 19.67 & 50.00 & 34.83 & 59.00 & 1.50 & 2.54 & $57.50-60.50$ & 24.20 & 69.39 & 18.00 & $76.36^{*}$ \\
\hline Cormlet weight (g) & 0.23 & 0.27 & 0.25 & 0.41 & 0.05 & 12.20 & $0.36-0.46$ & 0.20 & 65.33 & 51.22 & 0.00 \\
\hline Cormlet diameter (mm) & 5.76 & 11.02 & 8.39 & 8.46 & 0.69 & 8.12 & $7.98-9.25$ & 0.10 & 0.87 & -23.22 & $0.62^{\mathrm{ns}}$ \\
\hline Cormlet yield per plant (g) & 7.10 & 8.47 & 7.79 & 24.39 & 0.20 & 0.82 & $24.19-24.59$ & 16.60 & 213.05 & 187.80 & $0.05^{* *}$ \\
\hline Corm and cormlet yield per plant (g) & 27.20 & 55.00 & 41.09 & 112.6 & 0.36 & 0.32 & $112.20-112.90$ & 71.50 & 174.02 & 104.83 & $11.80 * *$ \\
\hline
\end{tabular}

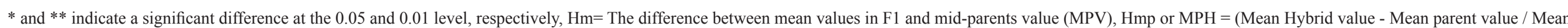
parent value $) \times 100$, Hsp or HPH $=($ Mean Hybrid value - High parent value $/$ High parent value $) \times 100$ 
Table 3. Genetic characteristics of ornamental traits in Gladiolus grandiflorus 'White Prosperity’ (p2: †), Gladiolus grandiflorus ‘Amsterdam’ (p1: §̋) and their F1 hybrid

\begin{tabular}{|c|c|c|c|c|c|c|c|c|c|c|c|}
\hline \multirow{2}{*}{ Ornamental traits } & \multicolumn{3}{|c|}{ Parent plants } & \multicolumn{7}{|c|}{ Hybrid F1 (opre57) } & \multirow{2}{*}{$\begin{array}{l}\text { Parent and F1 } \\
\text { Mean Square }\end{array}$} \\
\hline & q & $\hat{0}$ & MPV & mid-F1 value & SD & CV (\%) & Extreme value & $\mathbf{H m}$ & Hmp & Hsp & \\
\hline Plant height $(\mathrm{cm})$ & 128.0 & 143.2 & 135.61 & 135.0 & 6.75 & 5.00 & $128.30-141.80$ & -0.61 & -0.45 & -5.72 & $19.68 * *$ \\
\hline Num. of florets per spike & 12.10 & 16.5 & 14.31 & 12.7 & 2.91 & 22.92 & $10.51-16.00$ & -1.61 & -11.48 & -23.23 & $4.77 * *$ \\
\hline Peduncle length $(\mathrm{cm})$ & 19.94 & 20.53 & 20.24 & 15.67 & 4.64 & 29.53 & $12.4-21.00$ & -4.57 & -22.60 & -23.68 & $3.25^{*}$ \\
\hline Floret width (cm) & 8.39 & 9.43 & 8.91 & 8.33 & 1.49 & 17.85 & $7.13-10.00$ & -0.58 & -6.47 & -11.66 & $0.70 * *$ \\
\hline Floret length $(\mathrm{cm})$ & 6.59 & 7.82 & 7.20 & 7.33 & 0.68 & 9.21 & $6.65-8.00$ & 0.13 & 1.85 & -6.16 & $0.28 * *$ \\
\hline Leaf width $(\mathrm{cm})$ & 2.85 & 4.71 & 3.78 & 3.87 & 0.83 & 21.36 & $3.25-4.80$ & 0.09 & 2.29 & -17.85 & $0.32 * *$ \\
\hline Leaf length $(\mathrm{cm})$ & 51.30 & 59.30 & 55.30 & 62.33 & 16.35 & 26.22 & $50.40-81.00$ & 7.03 & 12.72 & 5.11 & $116.23 * *$ \\
\hline Stem diameter $(\mathrm{mm})$ & 10.67 & 18.08 & 14.38 & 8.26 & 2.99 & 36.22 & $6.20-11.70$ & -6.12 & -42.56 & -54.32 & $1.43 * *$ \\
\hline Spike length $(\mathrm{cm})$ & 42.47 & 52.25 & 47.36 & 43.67 & 13.40 & 30.69 & $34.20-59.00$ & -3.69 & -7.80 & -16.43 & $64.09^{* *}$ \\
\hline Bud diameter (mm) & 8.07 & 7.67 & 7.87 & 8.54 & 1.09 & 12.79 & $7.55-9.71$ & 0.67 & 8.47 & 11.35 & $1.07 * *$ \\
\hline Vase life (day) & 7.00 & 9.00 & 8.00 & 9.00 & 0.00 & 00.00 & $9.00-9.00$ & 1.00 & 12.50 & 0.00 & 0.00 \\
\hline Corm weight (g) & 20.11 & 46.50 & 33.30 & 40.57 & 0.51 & 1.25 & $39.99-40.89$ & 7.27 & 21.84 & -12.74 & $11.02 * *$ \\
\hline Corm diameter (mm) & 37.26 & 58.15 & 47.71 & 53.43 & 1.10 & 2.06 & $52.33-54.53$ & 5.72 & 11.99 & -8.12 & $56.44 * *$ \\
\hline Num. of cormlets per plant & 19.67 & 50.00 & 34.83 & 57.00 & 1.50 & 2.63 & $55.50-58.50$ & 22.17 & 63.65 & 14.00 & $76.36^{*}$ \\
\hline Cormlet weight (g) & 0.23 & 0.27 & 0.25 & 0.17 & 0.05 & 29.41 & $0.12-0.22$ & -0.08 & -32.00 & -56.55 & $0.007 * *$ \\
\hline Cormlet diameter (mm) & 5.76 & 11.02 & 8.39 & 4.79 & 0.66 & 13.74 & $4.07-5.36$ & -3.60 & -42.91 & 14.36 & $0.97 *$ \\
\hline Cormlet yield per plant (g) & 7.10 & 8.47 & 7.79 & 9.69 & 0.20 & 2.06 & $9.49-9.89$ & 1.90 & 24.39 & -8.56 & $0.05^{* *}$ \\
\hline $\begin{array}{l}\text { Corm and cormlet yield } \\
\text { per plant }(\mathrm{g})\end{array}$ & 27.20 & 55.0 & 41.09 & 50.30 & 0.34 & 0.68 & $49.88-50.53$ & 9.21 & 22.32 & & $11.69^{* *}$ \\
\hline
\end{tabular}

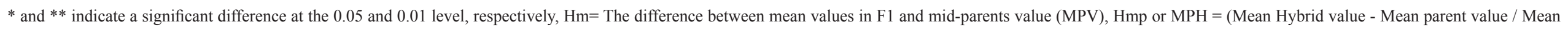
parent value $) \times 100, \mathrm{Hsp}$ or $\mathrm{HPH}=($ Mean Hybrid value - High parent value $/$ High parent value $) \times 100$ 


\section{Assessment of heritability and heterosis in traits}

The results revealed that the promising hybrid OPRC16 produced taller plants $(193.00 \mathrm{~cm})$ than its parents $(135.61$ $\mathrm{cm})$. The difference between OPRC16 and the mid-parent value in this trait was positive $(\mathrm{Hm}=57.40 \%)$ and it exhibited a positive heterosis $(\mathrm{Hsp}=34.78 \%)$ over parents and superior parent ('Amsterdam') (Table 2). OPRC57 had lower plant height than the parents. The difference in this trait between the hybrid and the mid-parent value was negative $(\mathrm{Hm}=-0.61)$. A negative heterosis $(\mathrm{Hsp}=$ $-5.72 \%)$ was observed over the parents $(\mathrm{Hmp}=-0.45)$ and the superior parent ('Amsterdam') (Table 3). The hybrid OPRC16, which showed a high positive heterosis over the superior parent and parents (maternal parent 'Amsterdam' and paternal parent 'White Prosperity'), can be used in breeding and quality improvement programs of gladiolus. A negative heterosis was observed for plant height in OPRC57 over the parents and the superior parent. These results imply that the diversity of plant height is mostly rooted in genetic factors, but it is less influenced by the environment.

The height of the flowering stem is another important trait for the marketability of cut flowers. Thus, this finding may imply that the higher the plant height is, the larger the dimension and number of leaf and other reproductive parts will be, and this will contribute to producing flowers with higher quality. Stem length and flowering branch length are invaluable features of the visual structure of gladiolus that improve the resistance of plants to the transport from farms to markets in addition to influencing their physiological traits. In the present study, the cormlets used were in the same size, so the difference observed in plant height of the gladiolus cultivars may arise from genetic structure and environmental factors, which is consistent with the findings of Hossain et al. (2012). Thus, selection for this trait can be effective. The difference in plant height may be related to their competition for light, moisture, space, nutrients, and aeration (Karavadi and Dhaduk, 2002). The increase in corm size of gladiolus resulted in higher plant height and flowering spike length. Similar results have been reported by Bijimol and Singh (2001) and Moradi (2013) for tuberoses.

The promising hybrid OPRC16 had more florets than the parents. The difference in this trait between the hybrid and the parents was positive $(\mathrm{Hm}=4.70)$. This hybrid had a positive heterosis over the parents and the superior parent ('Amsterdam') (Table 2). The number of florets per spike was fewer in OPRC57 than in the parents. The results revealed a negative difference $(\mathrm{Hm}=-1.61)$ in this trait between OPRC57 and the parents (Table 3). The heterosis was negative over both the parents $(\mathrm{Hmp}=-11.48 \%)$ and the superior parent 'Amsterdam' (Hsp=-23.23\%). OPRC16 showed a high positive heterosis over the superior parent and the parents in terms of floret number whereas the heterosis of OPRC57 over the parents and the superior parent was negative in this trait. These results imply that the diversity of floret number is mainly related to genetic factors, and environmental factors are involved in this trait to a less extent. Floret number is a key economic trait, so it is important to introduce commercial cultivars with higher number of florets (Azimi, 2020a).

For the trait of peduncle length, the parents outperformed the promising hybrids OPRC16 and OPRC57 (Table 2 and 3 ). Based on the results, the difference between the mean of the hybrids and the mid-parent value in this trait was negative. Heterosis was negative over the parent and the superior parent 'Amsterdam' (Tables 2 and 3).

The promising hybrid OPRC16 had higher floret width and length than the parents with the difference between the hybrid and the mid-parent value being positive for these traits. This hybrid exhibited a positive heterosis over the parents and the superior parent 'Amsterdam' (Table 2). The promising hybrid OPRC57 showed lower floret width and length than the parents. The results revealed that the difference between hybrid and the mid-parent value in these traits were $(\mathrm{Hm}=-0.58$ and 0.13$)$, respectively. For the trait of floret width, the heterosis over the parents and the superior parent ('Amsterdam') was negative (Table 3).

For the trait of floret length, heterosis was $1.85 \%$ over the mid-parent value and $-6.16 \%$ over the superior parent ('Amsterdam') (Table 3). The heterosis points to the relative superiority of F1 hybrids over the mid-parent value or the superior parent for this trait. Mousavi Bazzaz et al. (2007) reported the moderate superiority of hybrids for the traits of double flowers and flower size in stocks. According to the study of Arnold et al. (2010) on iris, the hybrids were superior to the parents in traits and the study of Azimi et al. (2018) on German iris revealed the superiority of some hybrids to the parents. OPRC16 out performed its parents in flower size. Flower size (floret width and length) is a major economic trait. Larger flowers increase flower sale in domestic and international markets and enhance the economic income as they give the plants more beauty and attractiveness (Azimi et al., 2012). This hybrid showed a positive heterosis in terms of flower size, so it can be included in breeding programs. Obviously, the introduction of commercial cultivars can contribute to the prosperity of flower industries of Iran by increasing the diversity in flower markets.

The results indicated that the hybrids OPRC16 and OPRC57 outperformed their parents in leaf width and length. The difference in these traits between the average of the promising hybrids and the mid-parent value was positive (Tables 2 and 3). The heterosis of leaf width in OPRC16 and OPRC57 was positive over the parents but it was -10.76 and -17.85 over the superior parent ('Amsterdam'), respectively (Tables 2 and 3) whilst it was positive over both parents and superior parent for the trait of leaf length (Tables 2 and 3). The promising hybrids exhibited a significant difference from their parents. Higher leaf area means higher photosynthesis, which increases carbohydrate accumulation. Furthermore, it influences the physiological traits of the flower and affects flower and cormlet yield of gladiolus. Cultivars that have higher leaf area show better quantitative and qualitative traits (Azimi and Banijamali, 2019). 
Based on the results, the differences of the average of OPRC16 and OPRC57 with the mid-parent value were -2.6 and -6.12 for this trait, respectively (Tables 2 and 3). The heterosis of stem diameter was negative for both hybrids as compared to their parents and the superior parent (Tables 2 and 3). Stem diameter (thickness) is a decisive factor dictating cut flower quality because not only does it determine stem strength, but it is also important for the vase life of cut flowers (Turkoglu et al., 2008). Flowering stem diameter is an invaluable feature of cut flowers so that it augments the resistance of plants during their transport from farms to markets (Azimi et al., 2012). In this respect, Moradi and Azimi (2017) evaluated the yield of different gladiolus cultivars and did not found any statistically significant differences in this trait among the cultivars. Likewise, Daneshvar and Heidary (2009) reported that planting type and inter-cormlet spacing had no significant effect on stem diameter of gladiolus.

The results revealed that the promising hybrid OPRC16 had higher spike length $(71.00 \mathrm{~cm})$ than its parents $(47.36$ $\mathrm{cm})$. The difference in this trait between OPRC16 and the mid-parent value was positive $(\mathrm{Hm}=23.60)$. So, it showed a positive heterosis over its parents and the superior parent (Table 2). However, OPRC57 produced shorter spikes than its parents. Indeed, the difference in this trait between this hybrid and the mid-parent value was negative $(\mathrm{Hm}=-3.69)$, indicating a negative heterosis over its parents and the superior parent (Table 3). The promising hybrid OPRC16 was superior to its parents in terms of spike length. Spike length is an economic trait, so it is important to introduce commercial cultivars with taller spikes (Chanda et al., 2000). As well, spike length is significantly increased by nutrient reserves of corms (Uddin et al., 2002; Bhat et al., 2009; Memon et al., 2009; Kareem et al., 2013) and the increase in planting spacing (Sharma and Goupa, 2003) due to the lower competition of the plants on water, minerals, nutrients, and radiation (Mojiri and Arzani, 2003). These results imply that the diversity in spike length is mainly related to genetic factors, and the environment (greenhouse conditions) is less involved in this trait.

The promising hybrids OPRC16 and OPRC57 had higher bud diameter than their parents, showing a positive difference from the mid-parent value. They had a positive heterosis over their parents and the superior parent in this trait (Tables 2 and 3). The hybrids differed from their parents significantly.

Based on the results, the promising hybrid OPRC16 had a significantly longer vase life (11.00 days) than their parents (8.00 days) and the difference between OPRC16 and the mid-parent value was positive (3.00 days) in this trait. It had a positive heterosis over its parents and the superior parent (Table 2). The vase life of the promising hybrid OPRC57 was one day longer than that of its parents. The difference between this hybrid and the mid-parent value was positive, but it did not differ from the superior parent (Table 3). Since a major goal in cut flower production is to produce larger flowers with higher stem strength, it has been suggested that the strength and thickness of flowers under the natural conditions plays a crucial role in their vase life (Daneshkhah et al., 2007). Longer vase life allows their transport to more remote export destinations. Thus, these hybrids can be used as candidate commercial cultivars in flower markets. Given the commercial and economic importance of cut flowers, it is critical to introduce cultivars with longer vase life. Vase life is influenced by preharvest and postharvest factors. The quality and vase life of cut flowers depend on growing conditions and their postharvest handling (Azimi and Banijamali, 2019).

OPRC16 and OPRC57 outperformed their parents in corm weight and diameter. A positive difference was observed in these traits between the hybrids and the midparent values (Tables 2 and 3). The heterosis of corm weight and diameter was 164.89 and $77.66 \%$ for the hybrid OPRC16 over its parents and 89.71 and $45.75 \%$ over the superior parent, respectively (Table 2). The heterosis of these traits in OPRC57 was positive over the parents but negative over the superior parent (Tables 2 and 3). OPRC16 and OPRC57 differed from their parents significantly.

In cormlet number, OPRC16 and OPRC57 performed better than their parents did so that their difference from the mid-parent value was positive in this trait. They showed a positive heterosis over their parents and the superior parent (Tables 2 and 3). The range of cormlet variations was 57.50-60.50 and 55.50-58.50 for OPRC16 and OPRC57, respectively. Sanjai and Singh (2000) reported that cormlet number varied from 18.7 to 55.5 in gladiolus cultivars and that 'White Prosperity' had the highest number of cormlets (50.2 cormlets). Propagation rate (cormlet number) in commercial cultivars of gladiolus is an important parameter to be considered.

The hybrid OPRC16 outperformed its parents in cormlet weight and diameter. It showed a positive heterosis over its parents and a negative heterosis $(\mathrm{Hsp}=-23.22 \%)$ over the superior parent ('Amsterdam') in terms of these two traits (Table 2). OPRC57 was not superior to its parents in cormlet weight and diameter. Its heterosis over its parents and the superior parent was negative (Table 3).

Corm and cormlet yield per plant were higher in OPRC16 and OPRC57 than in their parents. The difference between OPRC16 and the mid-parent value was strongly positive in these two traits. The heterosis of this hybrid for corm and cormlet yield per plant was 213.05 and $174.02 \%$ over the parents and 187.80 and $104.83 \%$ over the superior parent, respectively (Table 2). The heterosis of this hybrid in corm weight and diameter was positive over its parents but negative $(\mathrm{Hsp}=-23.22 \%)$ over the superior parent ('Amsterdam') (Table 2). OPRC57 exhibited higher corm and cormlet yield per plant than its parents. The heterosis values for these traits were 24.39 and $22.32 \%$ over the parents and 14.36 and $-8.56 \%$ over the superior parent, respectively (Table 3 ).

\section{Analysis of qualitative traits}

The flower color was white in parents but it was light coral and light pink in OPRC16 and OPRC57 (Table 4). 
Table 4. Ornamental traits in Gladiolus grandiflorus cv. 'Amsterdam' (p1), Gladiolus grandiflorus 'White Prosperity' (p2) and their F1 hybrids

\begin{tabular}{|c|c|c|c|c|}
\hline \multirow{2}{*}{ Ornamental traits } & \multicolumn{2}{|c|}{ Parents } & \multicolumn{2}{|c|}{ Hybrid F1 } \\
\hline & Amsterdam & White prosperity & oprc16 & Opre57 \\
\hline Flower color & White & White & Light coral & Light pink \\
\hline $\begin{array}{l}\text { Perianth tube: distribution of color spots in the } \\
\text { bottleneck }\end{array}$ & - & Interrupted band & $\begin{array}{l}\text { Continuous } \\
\text { band }\end{array}$ & - \\
\hline $\begin{array}{l}\text { Spike: arrangement of flowers } \\
\text { (one row, zig-zag, two rows, irregular) }\end{array}$ & One row & Irregular & One row & Irregular \\
\hline $\begin{array}{l}\text { Flower: shape in front view } \\
\text { (triangular, star-shaped, round) }\end{array}$ & Star-shaped & Star-shaped & Star-shaped & Star-shaped \\
\hline $\begin{array}{c}\text { Flower: attitude } \\
\text { (upright, semi-upright, horizontal) }\end{array}$ & Upright & Upright & Upright & Upright \\
\hline $\begin{array}{l}\text { Outer tepal: shape of blade } \\
\text { (ovate, Elliptic, obovate) }\end{array}$ & Elliptic & Obovate & Obovate & Obovate \\
\hline $\begin{array}{l}\text { Inner tepal: shape of macule } \\
\text { (type } 1 \text {, type } 2 \text {, type } 3 \text {, type } 4 \text { ) }\end{array}$ & $\begin{array}{c}\text { Type } 3 \\
\text { (the base) }\end{array}$ & $\begin{array}{c}\text { Type } 3 \\
\text { (the base) }\end{array}$ & $\begin{array}{c}\text { Type } 3 \\
\text { (the base) }\end{array}$ & $\begin{array}{l}\text { Type } 3 \\
\text { (the base) }\end{array}$ \\
\hline $\begin{array}{l}\text { Inner tepal: border of marginal zone (slightly, } \\
\text { irregular, moderately irregular, very irregular) }\end{array}$ & $\begin{array}{l}\text { Moderately } \\
\text { irregular }\end{array}$ & $\begin{array}{l}\text { Moderately } \\
\text { irregular }\end{array}$ & Slightly & Slightly \\
\hline $\begin{array}{c}\text { Median inner tepal: attitude } \\
\text { (semi-erect, semi-erect to horizontal, horizontal) }\end{array}$ & Semi-erect & Semi-erect & $\begin{array}{l}\text { Semi-erect to } \\
\text { horizontal }\end{array}$ & Semi-erect \\
\hline $\begin{array}{l}\text { Median inner tepal: attitude of apex (moderately } \\
\text { recurved, Straight, moderately reflexed, strongly } \\
\text { reflexed) }\end{array}$ & Straight & Straight & $\begin{array}{l}\text { Moderately } \\
\text { reflexed }\end{array}$ & Straight \\
\hline
\end{tabular}

The distribution of floret color in the bottleneck was in the form of red veins in 'White Prosperity' and the hybrids. The floret arrangement on spike was one-row in 'Amsterdam' and OPRC16 but irregular in 'White Prosperity' and OPRC57. The florets in the parents and hybrids were star-shaped. The petals were semi-erect in the parents and OPRC57 and semi-erect to horizontal in OPRC16. The form of floret standing on the spike was semi-upright in OPRC16 but upright in others. The shape of blade in the outer petal was elliptic in 'Amsterdam' and obovate in others. The form of color spots in inner petals was at the base or bottleneck in all parents and hybrids. The amount of wrinkles at the margins of inner petals was moderately irregular in the parents and lowly irregular in the hybrids. The form of the apex of the inner petal was straight in the parents and OPRC57 and moderately reflexed in OPRC16.

\section{Flower color analysis}

Flower color is one of the most appealing features of ornamental plants from the customers' and economic perspectives. A major goal of ornamental flowers and plants breeding programs is to manipulate flower color. In this work, flower color was measured by the digital imaging method using the color measurement software. The highest and lowest color variations were observed in OPRC16 and OPRC57 (76.3687.16), respectively (Table 5). The lowest color variation level (82.68-86.16) was observed in the parents (Table 5). 
Table 5. Color measurements of parents and their F1 hybrid performed on digital images and analyzed by using color tester software

\begin{tabular}{|c|c|c|c|c|}
\hline \multirow{2}{*}{ Color parameters } & \multicolumn{3}{|c|}{ Parent } & \multicolumn{2}{|c|}{ Hybrid F1 } \\
\hline Average Red & Amsterdam & White Prosperity & oprc16 & Oprc57 \\
\hline Average Green & 213.20 & 203.48 & 211.18 & 223.11 \\
\hline Average Blue & 214.27 & 202.37 & 102.26 & 207.65 \\
\hline Average Luminosity & 201.49 & 180.85 & 80.95 & 202.83 \\
\hline Average L Value & 195.81 & 181.53 & 137.47 & 86.57 \\
\hline Average a Value & 85.24 & 80.94 & 56.56 & -3.40 \\
\hline Average b Value & -6.91 & -7.38 & 37.15 & 9.60 \\
\hline Average Hue & 10.69 & 15.20 & 35.38 & 109.52 \\
\hline Average Chroma & 122.87 & 115.89 & 43.59 & 10.18 \\
\hline $\mathbf{\Delta E}$ & 12.73 & 16.89 & 51.31 & 87.16 \\
\hline
\end{tabular}

where: $a$ - tendency of flower color from green to red (- 70 for dark green and +70 for dark red); $b$ - tendency of flower color from blue to yellow (- 70 for blue and +70 for yellow); $L$ - brightness and lucidity of flower ( 0 for dark and 100 for white); $\Delta E$ - degree of color changing and its differences across flower.

The assessment of color tendency of flower from green to red (a) showed that the hybrid OPRC16 had the highest color tendency to red and 'White Prosperity' had the highest color tendency index to dark green. Based on the results for the tendency index of flower colors to blue-yellow (b), the hybrid OPRC16 had the highest color tendency to yellow and the promising hybrid OPRC57 had the highest tendency to blue (average blue $=207.65$ ) (Table 5). The highest color luminosity (average L of 202.83) was obtained from OPRC57. In a study on German iris, Azimi et al. (2017) found the highest heritability for the colors purple, violet, and white. Huang Su et al. (1998)'s study on iris revealed that the flower color inheritability was for a combination of purple.

\section{Conclusions}

Based on the results, when 'Amsterdam' is used as the maternal plant in crosses, it has more positive heterosis effects than when it is used as the paternal parent. These results indicate that major of traits in the phenotypic and genetic diversity coefficient was very low, indicating that they had less environmental effects, since the genotypes were cultivated under similar and controlled conditions. Most traits that were found to have high heritability are important in improving plant quality and quantity of Gladiolus. Promising hybrid OPRC57 showed a negative heterosis in most traits. Consequently, inter-varietal hybridization is an effective way to contribute to the phenotypic variations of Gladiolus, produce new plant materials for breeding purposes, and release new cultivars.

\section{Acknowledgements}

The financial support of Ornamental Plants Research Center (OPRC) is gratefully acknowledged.

\section{Author contribution}

M.H.A..$^{0000-0003-1533-1876}$ : designing the experiments, obtaining and analyzing data and writing the scientific article.

\section{References}

ANANDHI, S.; RAJAMANI, K.; JAWAHARLAL, M.; AHESHWARAN, M. M.; GNANAM, R. Interspecific hybridization in Glory lily. American International Journal of Research in Formal, Applied and Natural Sciences, v.2, n.10, p.13-135, 2013.

ANONYMOUS. Stats of ornamental plants in country. Office of flowers and ornamental plants, medicinal and edible mushrooms. Ministry of Jihade-e-Agriculture, 2015, p.15

ARNOLD, M.L.; TANG, S.; KNAPP, S.J.; MARTIN, N.H. Asymmetric ingressive hybridization among Louisiana Iris species. Genes, v.1, n.1, p.9-22, 2010. DOI: 10.3390/ genes1010009.

AZIMI, M.H. Progeny test of crosses among different cultivars of gladiolus. Journal of Plant Productions (Scientific Journal of Agriculture), v.41, n.4, p.31-42, 2019. DOI: 10.22055/PPD.2018.21501.1460. 
AZIMI, M. H.; Assessment and ranking of new gladiolus hybrids in Iran. Journal of Horticulture and Postharvest Research, v.3, n.2, p.235-244, 2020a. https://doi: 10.22077/ jhpr.2020.2972.1112.

AZIMI, M.H.; BANIJAMALI, S.M. Introducing superior cultivars of gladiolus by important quality and quantity indexes. Journal of Ornamental Plants, v.9, n.1, p.33-40, 2019.

AZIMI, M.H.; Evaluation yield and genetically factors in different cultivars of gladiolus. Ornamental Horticulture, v.26, n.1, p.8-17, 2020b. https://doi.org/10.1590/2447536x.v26i1.2027.

AZIMI, M.H.; JOZGHASEMI, S.; BARBA-GONZALEZ, R. Multivariate analysis of morphological characteristics in Iris germanica hybrids. Euphytica, v.214, p.161, 2018. DOI: $10.1007 / \mathrm{s} 10681-018-2239-7$

AZIMI, M.H.; SADEGHIAN, S.Y.; RAZAVI-AHARI, V.; KHAZAEI, F.; FATHI-HAFASHJANI, A. Genetic variation of Iranian Iris species using morphological characteristics and RAPD markers. International Journal of Agricultural Science, v.9, n.2, p.875-889, 2012.

BHUJBAL, G.B.; CHAVAN, N. G.; MEHETRE, S. S. Evaluation of genetic variability heritability and genetic advances in gladiolus (Gladiolus grandiflorus L.) genotypes. Supplement on Genetics and Plant Breeding, v.8, n.4, p.1515-1520, 2013.

BIJIMOL, G.; SINGH, A. Effect of spacing and nitrogen on gladiolus under Nagaland condition. Journal of Ornamental Horticulture New, v.4, n.1, p.36-39, 2001.

BOSE, T.K.; YADAV, L.P.; PAL, P. Gladiolus. In: BOSE, T.K.; YADAV, L.P.; PAL, P.; PARTHASARATHY, V.A.; DAS, D.P. Commercial Flowers. Naya Prokash: Department of Horticulture, Bidhan Chandra Krishi Viswavidyalaya, 2003. pp.33.

CHANDA, S.; BARMA, G.; ROYCHOWDHURY, N. Influence of different levels of nitrogen, phosphorus and potassium on growth and flowering of gladiolus. Indian Journal of Hort, v.13, p.76-86, 2000.

CHOUDHARY, M.; MOOND, S.K.; KUMARI, A. Correlation studies in Gladiolus. Research in Plant Biology, v.1, n. 4, p.68-72, 2011.

CLARKE, A.E.; CONSIDINE, J.A.; WARD, R.; KNOX, R.B. Mechanism of pollination in Gladiolus: roles of the stigma and pollen tube guide. Annals of Botany, v.41, n.171, p.15-20, 1977.
COHAT, J. Gladiolus. In: HERTOGH, A.; NARD, M.L. The physiology of flower bulbs. Amsterdam: Elsevier, 1993. p.320.

DANESHKHAH, M.; KAFI, M.; NIKBAKHAT, A.; MIRJALILI, M. Effect of nitrogen and potassium on performance indicators Rose flowers Barzoki Kashan, Iran. Journal of Horticultural Science and Technology, v.8, n.2, p.83-90, 2007.

DANESHVAR, M.H.; HEIDARI, M. Effect of row planting design and planting distance on flowering and quality of gladiolus cut flower (Gladiolus hybrida cv. Oscar). Journal of Plant Productions, v.3, n.6, p.129-140, 2013.

DHADUK, B.K.; SINGH, B.; DADLANI, N. K. Effect of different methods of pollination on seed set in gladiolus. South Indian Horticulture, v.35, n.3, p.260-265, 1987.

FAN, X. M.; ZHANG, Y. D.; YAO, W. H.; BI, Y. Q.; LIU, L.; CHEN, H. M.; KANG, M. S.; Reciprocal diallel crosses impact combining ability, variance estimation, and heterotic group classification. Crop Science, v.54, p.89-97, 2014. https://doi.org/10.2135/cropsci2013.06.0393.

GONZALEZ, A.; LOPEZ, J.; BANON, S.; OCHOA, J.; FERNANDEZ, J.A.; MARTINEZ, J.J.; RODRIGUEZ, R. Ornamental use of wild species of genus Gladiolus. Acta Horticulture, v.598, p.59-63, 2003.

HALLAUER, A.R.; CARENA, M.; MIRANDA, J.B. Quantitative genetics in maize breeding. In: RAJCAN, I.; VOLLMANN, J. Handbook of plant breeding. Iowa: Iowa State University Press, 1988. pp.1-31.

HELLER, J. Promoting the conservation and use of underutilized and neglected crops. Institute of Plant Genetic and Crop Plant Research, Gatersleben. Rome: International Plant Genetic Resource Institute, 1996. 44p.

HILL, J.; WAGOIRE, W.W.; ORITZ, R.; STOLEN, O. Analysis of a combined F1/F2 diallel cross in wheat. Theoretical and Applied Genetics, v.102, p.1076-1081, 2001.

HOSSAIN, M.D.; BHUIYAN, M.S.R.; TALUKDER, K.H.; ISLAM, M.R.; SYED, M.A. Study on vegetative propagating materials, flower characteristics and production of true seed through crossing among the different gladiolus genotypes. Advances in Biological Research, v.6, n.2, p.52-58, 2012.

HUANG SU, Z.; GU, Y.; HAN YU, L. The hybridization of Iris Spp. Journal of Plant Research and Environment, v.21, p.1- 14, 1998. 
JOSHI, S.P.; BHAVE, S.G.; CHOWDARI, K.V.; APTE, G.S.; DHONUKSHE, B.L.; LATITHA, K.; RANJEKAR, P.K.; GUPTA, V.S. Use of DNA markers in prediction of hybrid performance and heterosis for a three-line hybrid system in rice. Biochemical Genetics, v.39, n.5-6, p.179200, 2001. DOI: 10.1007/s10528-019-09935-z.

KUMAR, H.P.; KULKARNI, B.S.; JAGADEESHA, R.C.; REDDY, B.S.; SHIROL, A.M.; MULGE, R. Combining ability and heterosis for growth characters in gladiolus (Gladiolus hybridus. Hort). Karnataka Journal of Agricultural Science, v.21, n.4, p.544-547, 2008.

LARSON, R. Introduction to Floriculture. London: Academic Press, 1992. p.147.

MANNING, J.; GOLDBLATT, P. The Iris family: Natural history and classification. Portland: Timber Press, 2008. p.336.

MEMON, N.; QASIM, M.; JASKANI, M. J.; AHMED, R.; AHMED, I. Enhancement of corm and cormel production in gladiolus (Gladiolus spp.). New Zealand Journal of Crop and Horticultural Science, v.37, n.4, p.319-325, 2009.

MOJIRI, A.; ARZANI, A. Effects of nitrogen rate and plant density on yield and yield components of sunflower. Journal of Science and Technology of Agriculture and Natural Resources, v.7, n.2, p.115-125, 2003.

MORADI-ASHUR, B.; AZIMI, M. H. Increasing qualitative and quantitative indexes of Gladiolus grandifloras bush density and cultivation method. Scientific Journal of Promotion on Ornamental Flowers and Ornamental Plants, v.2, n.2, p.61-68, 2017.

OHRI, D.; KHOSHOO, T. N. Cytogenetics of garden gladiolus, III. Hybridization. Z.P flanzenzüchtg, v.91, p.46-60, 1983a.

OHRI, D.; KHOSHOO, T. N. Cytogenetics of garden gladiolus, IV. Origin and evolution of ornamental taxa. Proceeding of National Academy of Sciences, v.49, n.3, p.279-294, 1983b.

OHRI, D.; KHOSHOO, T.N. Cytogenetics of garden Gladiolus. I. Pollination mechanism and breeding system. Proceedings of the Indian National Science Academy, v.47, p.510-5151, 1981.

PATRA, S.K.; MOHANTY, C.R. Variability studies in gladiolus. The Asian Journal of Horticulture, v.9, n.2, p.352-355, 2014.

PATTANAIK, S.; PAUL, A; LENKA, P. C. Genotypic and phenotypic variability and correlation studies in gladiolus. Journal Crop and Weed, v.11, n.1, p.113-119, 2015.
POON, T. B.; POKHREL, A.; SHRESTHA, S.; SHARMA, S. R.; SHARMA, K. R.; DEV, M. B. L. Influence of intervarietal and interspecific crosses on seed set of gladiolus under mid-hill environments of Dailekh condition. Nepal Journal of Science and Technology, v.13, n.1, p.17-24, 2012.

PRAGYA, J. K. RANJAN, B. L. ATTRI, B. DAS, H. K. AHMED, N. Performance of gladiolus genotypes for cut flower and corm production under high altitude of Uttarakhand. Indian Journal of Horticulture, v.67, p.386-390, 2010.

RANDHAWA, S.; MUKHOPADHYAY, S. P. Promising varieties of gladiolus for commercial floriculture. Haryana Journal of Horticulture Science, v.24, n.3-4, p.197-203, 2000 .

RANJAN, P.; BHAT, K. V.; MISRA, R. L.; SINGH, S. K.; RANJAN, J. K. Relationship of Gladiolus cultivars inferred from fluorescence based on AFLP Markers. Science of Horticulture, v.123, n.4, p.562-567, 2010.

RASHMI, K.S. Estimation of Genetic Variability, Correlation and Path Analysis in Gladiolus (Gladiolus Species L.). International Journal of Plant Sciences, v.9, n.1, p.186-189, 2014.

ROY, S.M.; THAPLIYAL, R.C.; PHARTYAL, S.S. Seed source variation in cone, seed and seedling characteristic across the natural distribution of Himalayan low-level pine Pinus roxburghii. Sarg. Silvae Genetica, v.53, n.3, p.116123, 2004.

SANJAI, K. D.; SINGH, B. Gladiolus: A potential crop in Ladakh. Exploring the gladiolus in India. India: Proceedings of the National Conference on Gladiolus, 2000. p.75-77.

SCHWAB, N.T.; STRECK, N.A.; BECKER, C.C.; LANGNER, J.A.; UHLMANN, L.O.; RIBEIRO, B.R. A phenological scale for the development of Gladiolus. Annals of Applied Biology, v.166, p.496-507, 2015. DOI:10.1111/aab.12198.

SEMENOVA, M.N.; ROSHCHINA, V.V. Cholinesterase in anthers of higher plants. Soviet Plant Physiology, v.40, n.2, p.221-224, 1993.

SHARMA, J.R.; GOUPTA, R.B. Effect of corm size and spacing on growth, flowering and corm production in gladiolus. Journal of Ornamental Horticulture, v.6, p.352-356, 2003.

SINGH, A.K. Gladiolus. In: SINGH, A.K. Flower crops cultivation and management. New Delhi: Publishing Agency, 2006. p.47-166. 
SINGH, A. K.; MISHRA, S. P.; PARIHAR, R.; Studies on genetic variability parameters on grain yield and its yield attributing traits in maize (Zea mays L.). International Journal of Current Microbiology and Applied Sciences, v.7, p.1261-1266, 2018. https://doi.org/10.20546/ ijcmas.2018.709.150

STRECKER， J.; RODRÍGUEZ， G.; BREWER， M.; GONZALO, M.J.; ANDERSON, C.; LANG, L.; SULLIVAN, D.; WAGNER, E.; STRECKER, B.; DRUSHAL, R.; DUJMOVIC, N.; FUJIMURO, K.; JOSH, THOMAS, J.; GRAY, S.; KNAAP, E. Tomato Analyzer User Manual Version 3. Ohio: Ohio University, 2010.

SUKARIN, W.; YAMADA, Y.; SAKAGUCHI, S, Characteristics of physic nut, Jatropha curcas L. as a new biomass crop in the tropics. Japan Agricultural Research Quarterly, v.20, n.4, p.302-303, 1987.

TAKATSU, Y.; KASUMI, M.; MANABE, T.; HAYASHI, M. Temperature effects on interspecific hybridization between G. grandiflora and G. Tristis. Hortscience, v.36, n.2, p.341-343, 2001.
TURKOGLU, N.; ALP, S.; CIG, A. Effect of diamonium phoshate (DAP) fertilization in different doses on bulb and flower of Narcissus (Narcissus tazetta). AmericanEursian Journal Agricultural \& Environmental Sciences, v.4, n.5, p.595-598. 2008.

UPOV. 2013. Guidelines for the conduct of tests for distinctness, uniformity and stability. Gladiolus L. In: TG/108/4(proj.8). Netherlands: International union for the protection of new varieties of plants, 1997.

YANG, Y.; WEN, C.; MA, N.; ZHAO, L. Heterosis and genetic analysis of branching in cut-flower chrysanthemums. Euphytica, v.205, p.915-925, 2015. DOI: 10.1007/s10681015-1439-7

ZAMANI, Z.; ZAREI, A.; FATAHI, R. Characterization of progenies derived from pollination of pomegranate cv. Malase-Tourshe-Saveh using fruit traits and RAPD molecular marker. Scientia Horticulture, v.124, p.67-73, 2010. DOI: $10.1016 / j . s c i e n t a .2009 .12 .021$ 